\title{
Botrytis cinerea Airborne Conidia and Their Germination Ability Assessed by Immunological Methods in a NW Spain Vineyard
}

\author{
Estefanía González-Fernández ${ }^{1, * \mathbb{D}}$, Roy Kennedy ${ }^{2}$, Rachel Osborn ${ }^{2}$, María Fernández-González ${ }^{1}$ (D) and \\ Francisco Javier Rodríguez-Rajo ${ }^{1}$ D \\ 1 CITACA Agri-Food Research and Transfer Cluster, Department of Plant Biology and Soil Sciences, \\ Faculty of Sciences, Ourense Campus, University of Vigo, As Lagoas s/n, 32004 Ourense, Spain; \\ mfgonzalez@uvigo.es (M.F.-G.); javirajo@uvigo.es (F.J.R.-R.) \\ 2 AgriTech Animal and Plant Research Centre, Warwickshire Colleges, Pershore WR10 3JP, UK; \\ rkennedy@warwickshire.ac.uk (R.K.); rosborn@warwickshire.ac.uk (R.O.) \\ * Correspondence: estegonzalez@uvigo.es
}

\section{check for} updates

Citation: González-Fernández, E.; Kennedy, R.; Osborn, R.;

Fernández-González, M.;

Rodríguez-Rajo, F.J. Botrytis cinerea

Airborne Conidia and Their

Germination Ability Assessed by Immunological Methods in a NW Spain Vineyard. Agronomy 2021, 11, 1441. https://doi.org/10.3390/ agronomy11071441

Academic Editor: Jana Okleštková

Received: 25 June 2021

Accepted: 16 July 2021

Published: 20 July 2021

Publisher's Note: MDPI stays neutra with regard to jurisdictional claims in published maps and institutional affiliations.

Copyright: (C) 2021 by the authors. Licensee MDPI, Basel, Switzerland. This article is an open access article distributed under the terms and conditions of the Creative Commons Attribution (CC BY) license (https:// creativecommons.org/licenses/by/ $4.0 /)$.

\begin{abstract}
Grey mould is a fungal disease responsible for important crop losses in most winemaking regions worldwide. In the present study, we developed immunological techniques for the detection and quantification of Botrytis cinerea conidia germinative material to obtain additional information about epidemic's development on the vineyard. The study was carried out in a northwest Spain vineyard during the grapevine flowering in 2017 and 2018. An aerobiological study was developed for the identification and quantification of Botrytis cinerea conidia. For the immunological analysis, we developed a specific protein extraction protocol and a standard curve to analyze the cyclone-trap samples by an indirect PTA-ELISA. The airborne B. cinerea protein concentrations showed a similar variation pattern than the airborne conidia concentrations in the atmosphere of the vineyard. We recorded a total of 5673 B. cinerea spores in 2017, and 7562 spores in 2018. Regarding the airborne protein concentrations, we detected $9.692 \mathrm{ng} / \mathrm{m}^{3}$ in 2017 and $7.715 \mathrm{ng} / \mathrm{m}^{3}$ in 2018. Based on the statistical influence of the considered variables, we developed a predictive model able to explain $40 \%$ of protein data variability. The resulting methodology based on the combination of immunological techniques and aerobiological monitoring leads to a more reasoned treatment schedule consistent with real phytosanitary vineyard conditions and a more effective responsiveness against the increasing variability associated to climate change on the crop-pathogen system.
\end{abstract}

Keywords: Botrytis cinerea; conidia germinative material; aerobiological monitoring; meteorological conditions; immune-quantification; Vitis vinifera

\section{Introduction}

Fungal diseases affect crop production in most winemaking regions worldwide. Grey mould in grapevine, caused by Botrytis cinerea, is the third most reported disease in the European, North American and Australian vineyards, and the first cause of infection in South America, where the vine is irrigated [1]. The specific climatic conditions in the northwest Spain region, characterized by high relative humidity and moderate temperatures during the grapevine vegetative cycle favour the development of this fungal pathogen. Additionally, this fungus has a wide humidity and temperature tolerance range, which together to its ability to survive in the dry leaves and mummified grapes of the previous season enhance a constant and predominant presence of $B$. cinerea in many winegrowing regions [2-4].

Besides meteorological conditions and the presence of the pathogen, a susceptible host stage is required for the development of a fungal plant disease. This necessary condition known as disease triangle is one of the paradigms of plant pathology and supposes a 
valuable knowledge for Integrated Pest Management strategies, since plant disease can be prevented with the absence of any one of these factors [5,6]. Therefore, the analysis of airborne fungal propagules, meteorological conditions and crop phenology can be used for the determination of an optimal fungicide application schedule, which increases its effectiveness and improve the vineyard phytosanitary conditions. B. cinerea infection can develop on grapevine at any phenological stage. However, flowering and ripening of berries stages may be more susceptible to infection due to the presence of pollen and sugary exudates at flowering that enhance the colonization of plant tissues by the pathogen, and the increase in sugar concentration in the plant that takes place during the ripening stage $[7,8]$. Moreover, infection of floral debris can act as inoculum sources for late infections that affect during the ripening of berries stage leading to important yield losses [9-11].

Airborne fungal spore concentrations have been used as biological sensors of the pathogen's presence and the identification of infection cycles, providing a useful tool to an early disease detection before the appearance of symptoms on the crop [12-14]. Previous studies found a significant correlation between Botrytis squamosa aerial conidia at a given date and lesion density one week later in onion crops, both for managed and unmanaged sites, which shows the relation of disease development with spore concentrations during previous periods [15]. Furthermore, spores can be used for the evaluation of infection risk periods by the establishment of disease thresholds as a function of the airborne spore levels, distinguishing high-risk periods from low or moderate infection risk moments [16]. Airborne conidia are spread units designed for fungal propagation under favourable conditions that can indicate the disease potential. Besides this valuable information, in the case of $B$. cinerea we can take into account the real infective ability by immunodetection. This property can be assessed due to the specific antibodies designed for this pathogen react with a glycoprotein of the spore germinative tube or the hyphae cell wall, but not directly on conidia $[17,18]$.

In the present study, we applied immunological techniques for the detection and quantification of $B$. cinerea conidia germinative material, in order to provide epidemiological data and complement disease detection methods based on the combination of aerobiological, phenological and meteorological data. To achieve this objective, we developed a standard curve from fresh hoovered B. cinerea conidia and a specific extraction protocol for the optimization of protein detection in aerobiological samples from a cyclone-type trap. The obtained protein concentrations were related with $B$. cinerea spore levels and the meteorological parameters to determine the main influential factors on this variable.

\section{Materials and Methods}

\subsection{Study Area Description and Phenological Protocol}

The study was carried out during the 2017 and 2018 grapevine flowering period in a vineyard of the Ribeiro Protected Designation of Origin (PDO). The plot is located at Cenlle in northwest Spain, in the transitional area between the Atlantic and Mediterranean biogeographic regions (Figure 1). The Ribeiro PDO covers a total area of 2250 hectares, and it is situated in the confluence of the 'Miño', 'Avia', 'Arnoia' and 'Barbantiño' river valleys. Due to the transitional location of this winegrowing region, its Mediterranean character is softened by the Atlantic influence. However, this influence is not marked due to the orography of the mountain ranges that limits this PDO to the west and north, which act as natural barrier against sub-Atlantic storms. According to the Multicriteria Climatic Classification System (MCC), this winegrowing region would be described as temperate and warm, sub-humid, and with very cold nights [19]. Steep valleys and hillsides, with soils of granitic origin and a significant content in stones and gravel characterize the geomorphological structure of this area [20,21]. The sampling period for each year was identified as the overlapped period of the phenological flowering stage of four white preferential cultivars grown in the Galician Ribeiro PDO, 'Treixadura', 'Godello', 'Albariño' and 'Loureira'. 
Phenological observations were conducted on 22 plants of each variety following the $\mathrm{BBCH}$ (Biologische Bundesanstalt für Land und Forstwirtschaft, Bundessortenamt und CHemische Industrie) standardized scale [22]. The phenological study was applied during the flowering stage $(6-\mathrm{BBCH})$ in each year with twice per week frequency due to this stage has being usually the shortest and fastest over the grapevine vegetative cycle. This stage can be measured by means of phenological observations, considering the proportion of opened flowers, which can be identified by the fall of the calyptra, a structure formed by the fusion of the corolla petals that protect the reproductive whorls of the flower [23]. We tested three phenological phases, 61- Beginning of flowering: 10\% of flowerhoods fallen, 65- Full flowering: 50\% of flowerhoods fallen and 69- End of flowering with all calyptras fallen.

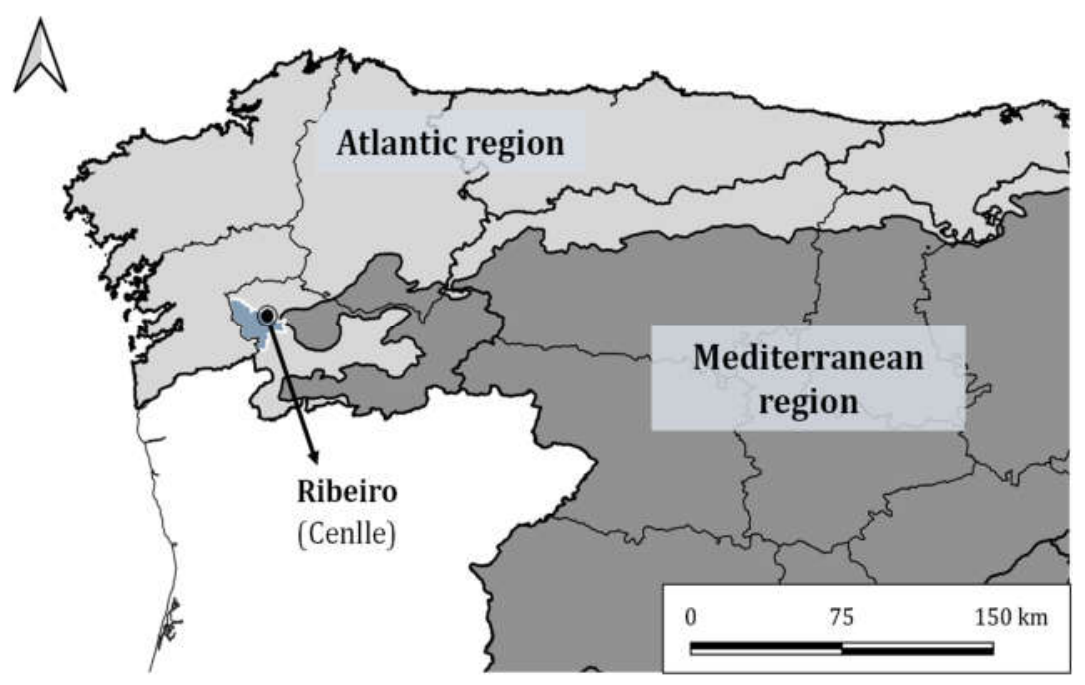

Figure 1. Location map of the studied vineyard in Cenlle, in the Ribeiro PDO situated at northwest Spain. Figure obtained by QGIS 3.10.14 software. Shapefile of biogeographic regions from MITECO [24].

\subsection{Meteorological Data}

Meteorological data were recorded by a HOBO meteorological micro station (ONSET HOBO USB Micro Station Data Logger) placed in the same location than the aerobiological samplers in the studied vineyard. The considered daily meteorological variables were the mean temperature $\left(\operatorname{Tmean},{ }^{\circ} \mathrm{C}\right)$, maximum temperature $\left(\operatorname{Tmax},{ }^{\circ} \mathrm{C}\right)$, minimum temperature (Tmin, $\left.{ }^{\circ} \mathrm{C}\right)$, relative humidity $(\mathrm{RH}, \%)$, dew point (DewP, $\left.{ }^{\circ} \mathrm{C}\right)$, rainfall $\left(\right.$ Rain, $\left.\mathrm{L} / \mathrm{m}^{2}\right)$ and wind speed (WindS, $\mathrm{km} / \mathrm{h}$ ). Information about rainfall and wind speed was obtained from the Leiro MeteoGalicia meteorological station situated at $5 \mathrm{~km}$ from the study plot [25].

\subsection{Aerobiological Study}

Aerobiological samples were obtained with a volumetric Hirst-type sampler [26] Lanzoni VPPS-2000 (Lanzoni s.r.l.) calibrated to obtain a constant air intake of $10 \mathrm{~L} / \mathrm{min}$, that was placed in the central part of the vineyard and at two meters above ground level to avoid sampling hindrance due to plant growth. The samples were processed following the Spanish Aerobiological Network protocol [27]. Air particles were trapped on a cylindrical drum covered by a Melinex tape, which was previously coated with a $2 \%$ silicone solution. The exposed tape was changed weekly and divided into seven pieces that were prepared on separated glass microscope slides using $1 \%$ basic fuchsin glycerinated gelatin as preparation medium. Microscope slides were analyzed under light optical microscope with a NIKON ECLIPSE E100 at 400× magnification. The target biological particles identified and quantified were B. cinerea conidia (Figure 2). B. cinerea conidia were identified as ellipsoidal and globose, hyaline or pale-grey becoming darker with age (sometimes pale-pink, depending on the preparation medium), unicellular, smooth, often 
with a slightly protuberant hilum on one side, and a mean side of $13 \mu \mathrm{m}$ length $\times 10.4 \mu \mathrm{m}$ width $[28,29]$. The obtained results were expressed as spores $/ \mathrm{m}^{3}$ referring to daily mean values [30].

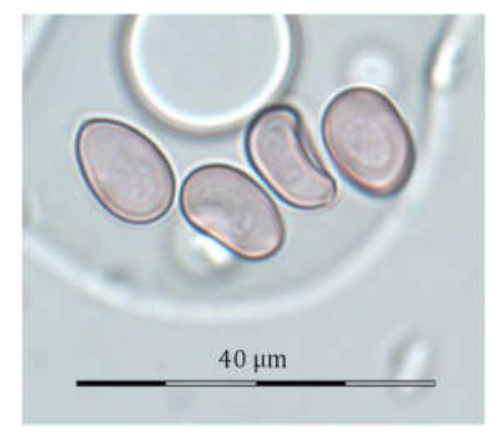

Figure 2. B. cinerea conidia in the aerobiological samples analyzed under light optical microscope at $400 \times$ magnification.

Airborne protein samples were obtained with a Burkard multi-vial cyclone sampler, placed at the same location than the Lanzoni volumetric trap. This sampler inputs a constant airflow of $16.5 \mathrm{~L} / \mathrm{min}$, generating a cyclonic stream inside each tube where the particles are deposited by the centrifuge force effect. This device has weekly autonomy due to the automated system for tube changing that moves the carousel formed by eight positions for $1.5 \mathrm{~mL}$ Eppendorf tubes. The obtained samples were stored at $-20{ }^{\circ} \mathrm{C}$ until processing.

\subsection{Immunological Assay}

\subsubsection{Protein Extraction Protocol}

A protocol was developed to maximize the extraction of protein particles from samples obtained by the cyclone sampler and apply on them a PTA-ELISA (Plate Trapped AntigenEnzyme Linked ImmunoSorbent Assay) protocol. The extraction volume was $200 \mu \mathrm{L}$ of $10 \mathrm{mM}$ sucrose per Eppendorf tube, and four replicates were analyzed for each sample. Three sequential FastPrep-24 ${ }^{\mathrm{TM}}$ (MP Biomedicals ${ }^{\mathrm{TM}}$, Santa Ana, CA, USA) agitations of $4 \mathrm{~m} / \mathrm{s}$ during $30 \mathrm{~s}$ were applied to the samples, with rest periods of $10 \mathrm{~min}$ at $4{ }^{\circ} \mathrm{C}$ between them. The FastPrep- $24^{\mathrm{TM}}$ device is a high-speed homogenizer that maximizes the protein concentration on the extraction diluent. We also added $25 \mathrm{mg}$ of borosilicate glass beads per Eppendorf to increase the protein extraction. The supernatant was then put into microtiter plates and incubated $24 \mathrm{~h}$ at $20^{\circ} \mathrm{C}$ in $10 \mathrm{mM}$ sucrose. The selected incubation medium was previously described as adequate for $B$. cinerea conidia germination [31]. A positive control stripe formed by 8 wells in the microtiter plate was added to test the antibody functioning, each well containing $100 \mu \mathrm{L}$ of fresh B. cinerea conidia dilution hoovered from a sporulating 8-days old culture of a B. cinerea standard isolate BC-8 (Agri-Tech Research Centre-WCG, Ely, UK), sub-cultured from BC-8 mycelium grown on PDA (potato dextrose agar). This positive control was added to the ELISA plate $24 \mathrm{~h}$ before the analysis, since it was incubated at $20^{\circ} \mathrm{C}$ with the rest of samples.

\subsubsection{Indirect PTA-ELISA}

After an incubation period of $24 \mathrm{~h}$ an indirect PTA-ELISA was applied, in which the target antigen remains fixed to the well surface. Wells were washed three times with $100 \mu \mathrm{L}$ PBS (phosphate buffered saline, Sigma-Aldrich, St Louis, MO, USA) during one minute to remove antigen debris that did not bound to the plate surface. A negative control stripe composed by 8 wells with no sample was added to the plate at the PBS-washes step to check the protocol effectiveness and determine the background signal. All wells were then blocked with $200 \mu \mathrm{L}$ of $1 \%(w / v)$ casein in PBS during $45 \mathrm{~min}$ at $250 \mathrm{rpm}$ and room temperature (RT) to prevent non-specific binding. Further, all wells were incubated 
at $250 \mathrm{rpm}$ and RT during $45 \mathrm{~min}$ with $100 \mu \mathrm{L}$ of BC12 (DSHB-Developmental Studies Hybridoma Bank; Dewey F.M., University of Oxford, Oxford, UK) as primary antibody diluted 1:16,000 in PBSTwC (PBS, 0.05\% Tween 20 and $0.1 \%$ casein $[w / v]$ ). As secondary antibody we used a biotinylated anti-mouse IgM diluted 1:500 in PBSTwC, adding $100 \mu \mathrm{L}$ to all wells and incubating them during $45 \mathrm{~min}$. After that, the wells were incubated during 30 min with $100 \mu \mathrm{L}$ of $\mathrm{A}+\mathrm{B}$ Vectastain reagent. This last reagent is an avidin/biotin-based peroxidase system (VECTASTAIN ${ }^{\circledR}$ Elite ABC-HRP kit Peroxidase-Standard PK-6100, Vector Laboratories Inc., Burlingame, CA, USA) that binds to the biotinylated secondary antibody, amplifying the generated colorimetric signal due to the avidin-biotin complex properties. Finally, $100 \mu \mathrm{L}$ of TMB (3,3',5,5'Tetramethyl-benzidine dihydrochloride) were added to each well as peroxidase substrate, and then stored in the dark for $10 \mathrm{~min}$. Three washes of $200 \mu \mathrm{L}$ PBSTwC during one minute were applied to all wells between each step to remove weak and non-specific binding, except before to the TMB addition step, when four washes were applied. The reaction was stopped by adding $25 \mu \mathrm{L}$ of $1.5 \mathrm{M}$ sulphuric acid to each well, and the generated colorimetric signal was read at a wavelength of $450 \mathrm{~nm}$ on a microplate reader.

\subsubsection{Development of a Standard Curve}

A standard curve was developed from fresh B. cinerea conidia hoovered with a Burkard cyclone surface sampler from a sporulating 8-days old culture of the standard isolate BC8 (Plant Pathology Lab., Agri-Tech Research Centre-WCG, Ely, UK) grown on strawberry culture medium at $20{ }^{\circ} \mathrm{C}$. The hoovered conidia were diluted in $1 \mathrm{~mL}$ of $10 \mathrm{mM}$ sucrose and the initial concentration of the conidial suspension was determined by a Neubauer chamber (B.S.748 WEBER SCIENTIFIC, Teddington, UK) under light optical microscope at $400 \times$ magnification. Serial dilutions 1:10, 1:100, 1:1000, 1:5000, 1:10,000, 1:20,000, 1:40,000 and $1: 80,000$ were applied to the initial conidial suspension, obtaining the final concentrations of $6.8 \times 10^{5}, 6.8 \times 10^{4}, 6.8 \times 10^{3}, 1.4 \times 10^{3}, 6.8 \times 10^{2}, 3.4 \times 10^{2}, 1.7 \times 10^{2}$ and $8.5 \times 10$ conidia/mL. A volume of $100 \mu \mathrm{L}$ of each obtained dilution was transferred to an ELISA plate and incubated $24 \mathrm{~h}$ at $20{ }^{\circ} \mathrm{C}$ to apply a PTA-ELISA on them. A control stripe of eight empty wells was added to the plate for the assessment of the background signal, following the entire protocol but without initial conidia dilution on the wells. The obtained absorbance values of the different conidia concentrations were used to fit a standard logarithmic curve, which showed an Adjusted Coefficient of Determination $\mathrm{R}^{2}$ of 0.989 (Figure 3).

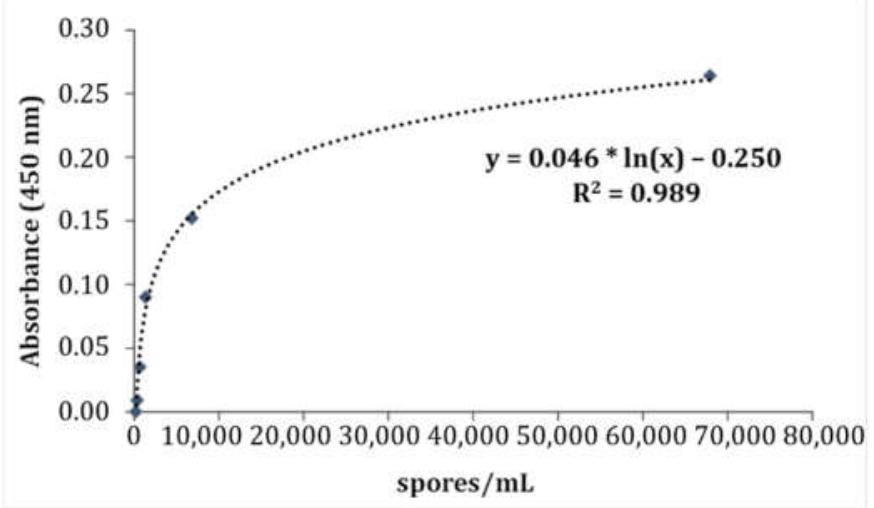

Figure 3. Standard curve developed from fresh B. cinerea conidia, obtained from the relation between conidia concentrations and the generated absorbance values. Dark blue points represent the absorbance value of each concentration point (in spores $/ \mathrm{mL}$ ). Discontinuous line represents the logarithmic curve to which data fitted, defined by the mathematical expression presented in the $\operatorname{chart}\left(y, R^{2}\right)$. 


\subsection{Statistical Analysis}

For the statistical analysis of the obtained data, we applied correlation analysis to assess the influence of meteorological conditions on the presence of $B$. cinerea conidia in the vineyard atmosphere and their germination ability. Firstly, we applied a Principal Component Analysis (PCA) to determine the statistical relation between airborne conidia and protein concentrations with the main meteorological parameters, which is a nonparametric test that determines the influence of the studied variables together classifying them as supra-variables reducing the dimensionality of the considered variables. This method is a standardized projection that maximizes the variance in the projected space [32]. The minimum eigenvalue was considered as 1.0 , and the missing value treatment was Listwise (case deletion). We applied this statistical procedure for 2017 and 2018 data as separate to consider inter-annual differences. In addition, we applied the non-parametric Spearman's correlation test due to the not normal distribution of most variables. This statistical test was applied on aerobiological and meteorological data, considering variables of the same day and the previous 1 to 7 days, since weather conditions could affect conidia production and germination both directly or indirectly through their effect on colonized substrates by the fungus. This 1-7 days period was previously considered as necessary for the fungus to complete a disease cycle and sporulation $[3,15]$. Significant correlations were considered at a confidence interval of $90 \%(p \leq 0.1), 95 \%(p \leq 0.05)$ and $99 \%(p \leq 0.01)$. These correlations between the considered meteorological variables and the airborne conidia and protein concentrations were obtained from the 2017 dataset. Based on the obtained Spearman's test results, we applied a multiple lineal regression analysis to develop a predictive model for the airborne protein concentrations as a function of the main influential factors. The 2017 dataset was used for model development, validating the obtained model with the 2018 dataset not included for model training. Model accuracy was statistically assessed by means of a $t$-test for dependent samples between real 2018 protein concentrations and the estimated values for the same year obtained from the developed model.

Regarding the immunological methodology, the replicability of the analysis was assessed by a one-way ANOVA test to evaluate the homogeneity of replicates. The absorbance values obtained for each one of the four replicates was considered as a group (dependent variable). The number of replicates was considered as the factor (independent variable). The null hypothesis indicates that the means are all equal, contrasting the obtained $p$-value with $\alpha(0.05)$ to accept or reject the null hypothesis. In the case that significant differences between the means were found, we would apply the post-hoc multiple-comparison Tukey HSD (Honestly Significant Difference) and Scheffé tests to determine which means differ.

The statistical software used for statistical analysis were the STATGRAPHICS Centurion XVI 16.1.11 (2010 StatPoint Technologies, Inc., Warrenton, VA, USA), STATISTICA 8.0 (StatSoft Inc., Tulsa, OK, USA) and SPSS Statistics 25 (IBM Corporation, Armonk, New York, NY, USA).

\section{Results}

\subsection{Immunological Assay Replicability and Aerobiological Study}

The absorbance values of the four replicates per sample were analyzed by means of a one-way ANOVA to compare the means and to assess the replicability of the immunological assay and the goodness of this technique. The applied ANOVA test did not find statistically significant differences between the four replicates in any studied year, with $\mathrm{F}(3,135)=0.505, p=0.679$ in 2017 , and $\mathrm{F}(3,106)=1.232, p=0.302$ in 2018. Since the $p$-value was higher than $\alpha$ level in both cases, we can't reject the null hypothesis of this statistical test and we accept that there are no statistically significant differences between the means. Daily absorbance values were obtained as the mean value of the four replicates for each daily sample, subtracting the background signal of the corresponding plate. This background was determined from the mean value of the negative control stripe composed by eight wells added to each plate. 
Protein concentrations were obtained from the absorbance signal generated by the samples interpolated through the developed standard curve, in which we determined the relation between conidia concentrations and absorbance values. The obtained concentrations in conidia $/ \mathrm{mL}$ units were transformed to $\mathrm{ng} / \mathrm{m}^{3}$ applying a correction factor for the comparison of this variable with the airborne conidia levels in spores $/ \mathrm{m}^{3}$. This factor was developed considering the initial volume added to each Eppendorf tube during the extraction protocol and the sampled air volume on each tube during $24 \mathrm{~h}$, calculated from the device specifications. We observed a similar variation pattern for both airborne $B$. cinerea conidia and protein concentrations, especially in 2017, despite there were obtained by different aerobiological samplers, which shows the effectiveness of the applied methodology on pathogen detection (Figure 4). We recorded a total of 5673 B. cinerea spores in 2017, and 7562 spores in 2018. Regarding the airborne protein concentrations, we detected $9.692 \mathrm{ng} / \mathrm{m}^{3}$ in 2017 and $7.715 \mathrm{ng} / \mathrm{m}^{3}$ in 2018. The functioning characteristics of both devices, a volumetric Hirst sampler and a Burkard cyclone sampler, such as the airflow input or the generated current inside the sampler, can influence on the difference found between both biological variables. In addition, the target element and sample processing also varied in both cases, since airborne conidia were identified by means of a non-viable method while the glycoprotein derived from conidia germination tube was detected by an immunological assay that needs cell viability for germination. Thus, reinforcing the goodness of the developed technique due to the similar variations of values of both variables.

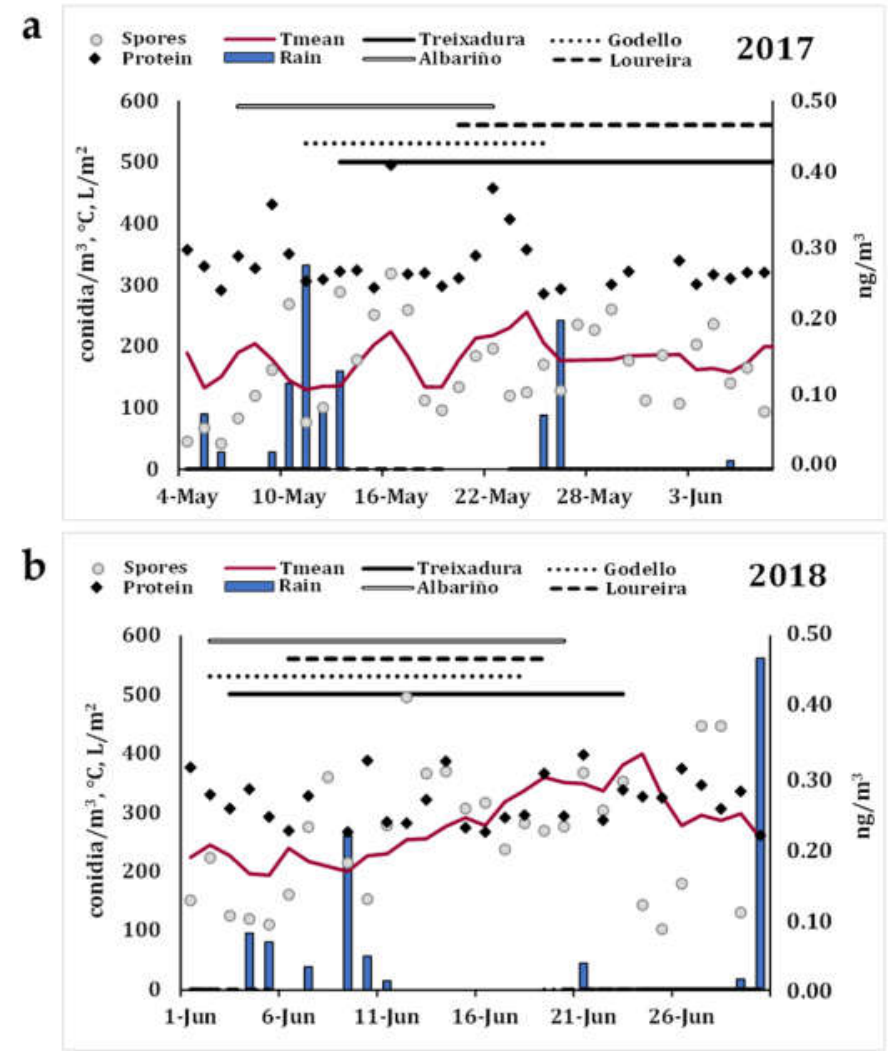

Figure 4. Airborne B. cinerea conidia concentrations (Spores, spores $/ \mathrm{m}^{3}$ ), airborne B. cinerea protein concentrations (Protein, $\mathrm{ng} / \mathrm{m}^{3}$ ), and the meteorological conditions of mean temperature in ${ }^{\circ} \mathrm{C}$ (Tmean) and rainfall in L/m² (Rain) during the study period in 2017 (a) and 2018 (b), considering the flowering stage of the grapevine varieties 'Treixadura', 'Godello', 'Albariño' and 'Loureira'. (a): Spores $\times 1.5$, Tmean $\times 10$, Rain $\times 10$ (Tables S1 and S2). (b): Tmean $\times 15$, Rain $\times 15$ (Tables S3 and S4).

Regarding the B. cinerea conidia concentrations, we observed a constant presence along the study period in both years, defined by the flowering phenological stage of the 
considered grapevine varieties. We started sampling some days in advance to the flowering beginning in 2017 and the sampling period was maintained a few days after the end of flowering in the case of 2018, since phenological events are not exactly simultaneous in all plants of the vineyard.

The highest daily B. cinerea airborne conidia concentrations were recorded in midMay in 2017, with concentrations of 319 spores $/ \mathrm{m}^{3}$ on 16 May followed by 288 spores $/ \mathrm{m}^{3}$ on 13 May. These concentrations were detected in the first fortnight of May, coinciding with an important increase in mean temperature of $9{ }^{\circ} \mathrm{C}$, from the $13.6^{\circ} \mathrm{C}$ detected on 13 May to $22.4^{\circ} \mathrm{C}$ on $16 \mathrm{May}$, and a humid period after a continuous-rain period that occurred from 9 to 13 May (Figure 4). In the case of 2018, we detected two main periods with the highest daily B. cinerea concentrations, from 12-15 June, in which the maximum peak was detected on 13 June with 495 spores $/ \mathrm{m}^{3}$, and 28-29 June, both days with a concentration of 446 spores $/ \mathrm{m}^{3}$. During the first peak, we also detected an increase in temperature, rising from $16.9^{\circ} \mathrm{C}$ on 12 June to $19.4{ }^{\circ} \mathrm{C}$ on 15 June, and a previous period of continuous rain, from 4 to 11 June. During this rainy period, the high humidity conditions also enhanced the presence of airborne conidia increasing their atmospheric concentration. The temperature increase continued over the study period, until the maximum values of $26.6^{\circ} \mathrm{C}$ mean temperature and $35.7^{\circ} \mathrm{C}$ maximum temperature on 24 June. From this point, temperature decreased and stabilized around $20^{\circ} \mathrm{C}$ mean temperature, from 25 June to the end of the study period, when the second peak was detected, from 28-29 June. Additionally, a humid period was also detected, since a slight rain occurred on 29 June with $1.2 \mathrm{~L} / \mathrm{m}^{2}$ (Figure 4).

\subsection{Statistical Analysis of the Influence of Meteorological Conditions}

Weather conditions are an important environmental factor that affect B. cinerea airborne particle transport and germination process. We statistically analyzed the influence of meteorological conditions on the airborne levels of the pathogen's conidia and protein particles by means of a Principal Component Analysis (PCA) for each studied year. The PCA analysis for 2017 between the main meteorological variables with airborne conidia and protein concentrations, extracted three Principal Components (PC) that accounted for the $78.85 \%$ of the variance of the data (Table 1). The first component (PC1) explained the $41.19 \%$ of variance and it grouped the protein concentrations with mean and maximum temperatures, showing the influence of these thermal variables on airborne protein concentrations and the germination process. The second component (PC2), which explained the $24.35 \%$ of variance, included the meteorological variables of minimum temperature, relative humidity, dew point and rainfall. Finally, the third component (PC3) grouped the conidia concentrations with wind speed, explaining the $13.31 \%$ of variance (Figure 5). The 2018 PCA also extracted three Principal Components that accounted for the 78.71\% of data variance (Table 2). The first component (PC1) explained the $47.07 \%$ of variance and grouped the temperature-related variables of mean and maximum temperatures with relative humidity and dew point. The second component (PC2) explained the $19.37 \%$ of variance and grouped the minimum temperature with rainfall and wind speed. In the third component (PC3), which explained the $12.28 \%$ of total variance, there were grouped the airborne conidia and protein concentrations with an inverse influence as the coefficient's sign indicated (Figure 6). 
Table 1. Principal Component Analysis coefficients for 2017 and factor loadings of the considered variables. In bold, the largest correlation coefficient for each variable.

\begin{tabular}{cccc}
\hline $\mathbf{2 0 1 7}$ & PC1 & PC2 & PC3 \\
\hline Eigenvalue & 3.707 & 2.191 & 1.198 \\
Variance \% & 41.190 & 24.345 & 13.313 \\
Cumulative \% & 41.190 & 65.534 & 78.848 \\
\hline Spores & 0.153 & 0.151 & $\mathbf{0 . 6 8 3}$ \\
Protein & $\mathbf{0 . 2 7 4}$ & -0.049 & 0.025 \\
Tmean & $\mathbf{0 . 5 0 8}$ & 0.026 & -0.060 \\
Tmax & $\mathbf{0 . 4 8 0}$ & -0.144 & -0.066 \\
Tmin & 0.299 & $\mathbf{0 . 4 8 1}$ & 0.013 \\
RH & -0.355 & $\mathbf{0 . 4 5 1}$ & 0.192 \\
DewP & 0.318 & $\mathbf{0 . 4 7 6}$ & 0.153 \\
Rain & -0.276 & $\mathbf{0 . 4 6 4}$ & -0.210 \\
WindS & -0.143 & -0.275 & $\mathbf{0 . 6 4 8}$ \\
\hline
\end{tabular}

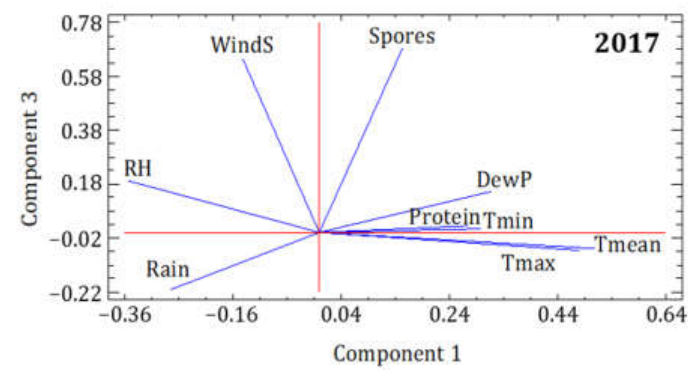

Figure 5. Graph of component weights of the considered variables for the 2017 Principal Component Analysis, representing CP3 vs. CP1.

Table 2. Principal Component Analysis coefficients for 2018 and factor loadings of the considered variables. In bold, the largest correlation coefficient for each variable.

\begin{tabular}{cccc}
\hline $\mathbf{2 0 1 8}$ & PC1 & PC2 & PC3 \\
\hline Eigenvalue & 4.236 & 1.743 & 1.105 \\
Variance \% & 47.065 & 19.365 & 12.281 \\
Cumulative \% & 47.065 & 66.429 & 78.710 \\
\hline Spores & 0.214 & -0.119 & $-\mathbf{0 . 7 0 3}$ \\
Protein & 0.100 & -0.298 & $\mathbf{0 . 5 9 6}$ \\
Tmean & $\mathbf{0 . 4 7 7}$ & 0.102 & 0.022 \\
Tmax & $\mathbf{0 . 4 6 8}$ & 0.010 & -0.084 \\
Tmin & 0.382 & $\mathbf{0 . 3 8 6}$ & 0.207 \\
RH & $-\mathbf{0 . 3 6 4}$ & 0.360 & 0.187 \\
DewP & $\mathbf{0 . 4 0 0}$ & 0.377 & 0.171 \\
Rain & -0.197 & $\mathbf{0 . 5 0 6}$ & -0.080 \\
WindS & 0.144 & $-\mathbf{0 . 4 5 7}$ & 0.172 \\
\hline
\end{tabular}

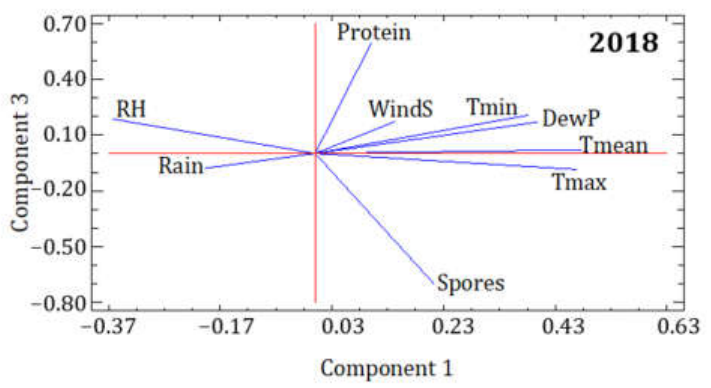

Figure 6. Graph of component weights of the considered variables for the 2018 Principal Component Analysis, representing CP3 vs. CP1.

The applied Spearman's correlation test showed some differences depending on the considered biological variable, airborne conidia or protein concentrations. In the case of 
conidia, we found the strongest correlations $(p \leq 0.01)$ with protein concentration of 6 days before, mean temperature of 6 and 7 days before, maximum temperature of 6 days before, minimum temperature of 5 and 6 days before, dew point of 5 and 6 days before, rainfall of 3 and 4 days before and wind speed of 6 days before (Table 3). Regarding the protein concentrations, we found the strongest correlations with mean temperature of 3 days before, maximum temperature of 3 and 4 days before, relative humidity of the same day, and dew point of 3 days before (Table 4). Based on the obtained Spearman's correlations, we obtained a significant regression model that represents a significant relation between $B$. cinerea airborne conidia and protein concentrations, able to explain $40 \%$ of protein data variability, with a F-value 8.470 (df 3, 31) (Table 5). The selected independent variables in the regression equation were the airborne conidia concentrations, relative humidity and dew point of four days before. We found a negative statistical influence of both water-related variables, relative humidity and dew point of four days before, on airborne protein concentrations, as their negative coefficients showed. Despite the obtained model being trained with a dataset obtained from a short time period, from 4 May to 11 June in 2017, it provided a valuable predictive ability of $40 \%$ of the objective data. The 2018 dataset, from 1 to 30 June in 2018, was used for model validation and not included for model development (Figure 7). According to the statistical $t$-test applied on 2018 data, we did not find statistically significant differences between real and forecast values of protein concentrations at 95\% confidence level ( $p$-value 0.118) (Table 6).

Table 3. Spearman's correlation coefficients between airborne conidia concentrations and the considered aerobiological and meteorological variables.

\begin{tabular}{|c|c|c|c|}
\hline Variables & Spearman $\mathbf{R}$ & Variables & Spearman $\mathbf{R}$ \\
\hline Protein & 0.202 & Relative Humidity & 0.041 \\
\hline Protein-1 & 0.011 & Relative Humidity-1 & 0.075 \\
\hline Protein-2 & $-0.424^{* *}$ & Relative Humidity -2 & $0.348^{* *}$ \\
\hline Protein-3 & -0.232 & Relative Humidity -3 & 0.305 * \\
\hline Protein-4 & -0.137 & Relative Humidity -4 & 0.227 \\
\hline Protein-5 & 0.242 & Relative Humidity -5 & 0.034 \\
\hline Protein-6 & $0.545^{* * *}$ & Relative Humidity-6 & -0.213 \\
\hline Protein-7 & 0.077 & Relative Humidity -7 & 0.004 \\
\hline Mean Temperature & 0.277 & Dew Point & $0.365^{* *}$ \\
\hline Mean Temperature-1 & 0.178 & Dew Point-1 & $0.363^{* *}$ \\
\hline Mean Temperature -2 & -0.094 & Dew Point-2 & 0.186 \\
\hline Mean Temperature-3 & -0.205 & Dew Point-3 & 0.036 \\
\hline Mean Temperature-4 & -0.055 & Dew Point-4 & 0.237 \\
\hline Mean Temperature -5 & $0.316 *$ & Dew Point -5 & $0.447^{* * *}$ \\
\hline Mean Temperature-6 & $0.584 * * *$ & Dew Point-6 & $0.489 * * *$ \\
\hline Mean Temperature -7 & $0.498^{* * *}$ & Dew Point -7 & $0.386^{* *}$ \\
\hline Max. Temperature & 0.202 & Rainfall & -0.119 \\
\hline Max. Temperature-1 & 0.130 & Rainfall-1 & -0.117 \\
\hline Max. Temperature -2 & -0.190 & Rainfall-2 & 0.149 \\
\hline Max. Temperature-3 & $-0.299 *$ & Rainfall-3 & $0.453^{* * *}$ \\
\hline Max. Temperature-4 & -0.206 & Rainfall—4 & $0.442 * * *$ \\
\hline Max. Temperature -5 & 0.204 & Rainfall -5 & 0.133 \\
\hline Max. Temperature-6 & $0.526^{* * *}$ & Rainfall-6 & -0.143 \\
\hline Max. Temperature-7 & $0.407^{* *}$ & Rainfall-7 & -0.077 \\
\hline Min. Temperature & 0.199 & Wind Speed & 0.103 \\
\hline Min. Temperature-1 & $0.290 *$ & Wind Speed-1 & -0.051 \\
\hline Min. Temperature-2 & 0.118 & Wind Speed-2 & 0.024 \\
\hline Min. Temperature -3 & -0.021 & Wind Speed-3 & 0.106 \\
\hline Min. Temperature-4 & $0.351 * *$ & Wind Speed-4 & -0.029 \\
\hline Min. Temperature -5 & $0.444^{* * *}$ & Wind Speed-5 & $-0.332 *$ \\
\hline Min. Temperature-6 & $0.511^{* * *}$ & Wind Speed-6 & $-0.480^{* * *}$ \\
\hline Min. Temperature -7 & $0.319 *$ & Wind Speed-7 & -0.254 \\
\hline
\end{tabular}


Table 4. Spearman's correlation coefficients between airborne protein concentrations and the considered aerobiological and meteorological variables.

\begin{tabular}{|c|c|c|c|}
\hline Variables & Spearman $\mathbf{R}$ & Variables & Spearman $\mathbf{R}$ \\
\hline Spores & $0.202 * *$ & Relative Humidity & $-0.444^{* * *}$ \\
\hline Spores-1 & -0.018 & Relative Humidity-1 & $-0.325 *$ \\
\hline Spores-2 & $-0.322 *$ & Relative Humidity-2 & 0.003 \\
\hline Spores-3 & -0.258 & Relative Humidity-3 & 0.239 \\
\hline Spores-4 & $-0.315^{*}$ & Relative Humidity-4 & 0.171 \\
\hline Spores-5 & -0.230 & Relative Humidity -5 & -0.020 \\
\hline Spores-6 & 0.036 & Relative Humidity-6 & -0.228 \\
\hline Spores-7 & 0.038 & Relative Humidity -7 & -0.018 \\
\hline Mean Temperature & $0.283^{*}$ & Dew Point & -0.059 \\
\hline Mean Temperature-1 & 0.229 & Dew Point-1 & -0.161 \\
\hline Mean Temperature-2 & -0.237 & Dew Point-2 & $-0.334^{* *}$ \\
\hline Mean Temperature-3 & $-0.519^{* * *}$ & Dew Point-3 & $-0.502 * * *$ \\
\hline Mean Temperature-4 & $-0.407^{* *}$ & Dew Point-4 & $-0.339 * *$ \\
\hline Mean Temperature -5 & -0.129 & Dew Point -5 & -0.048 \\
\hline Mean Temperature-6 & 0.186 & Dew Point-6 & 0.102 \\
\hline Mean Temperature-7 & 0.106 & Dew Point-7 & 0.173 \\
\hline Max. Temperature & $0.341^{* *}$ & Rainfall & -0.187 \\
\hline Max. Temperature-1 & $0.302 *$ & Rainfall-1 & -0.177 \\
\hline Max. Temperature-2 & -0.193 & Rainfall-2 & -0.075 \\
\hline Max. Temperature-3 & $-0.431^{* * *}$ & Rainfall-3 & 0.266 \\
\hline Max. Temperature-4 & $-0.442^{* * *}$ & Rainfall-4 & 0.157 \\
\hline Max. Temperature -5 & -0.088 & Rainfall-5 & 0.010 \\
\hline Max. Temperature-6 & 0.205 & Rainfall-6 & $-0.325^{*}$ \\
\hline Max. Temperature-7 & 0.076 & Rainfall-7 & -0.017 \\
\hline Min. Temperature & 0.038 & Wind Speed & -0.131 \\
\hline Min. Temperature-1 & -0.054 & Wind Speed-1 & -0.108 \\
\hline Min. Temperature-2 & $-0.287^{*}$ & Wind Speed-2 & -0.022 \\
\hline Min. Temperature-3 & $-0.368^{* *}$ & Wind Speed-3 & 0.118 \\
\hline Min. Temperature-4 & $-0.307 *$ & Wind Speed-4 & 0.082 \\
\hline Min. Temperature-5 & 0.010 & Wind Speed-5 & 0.080 \\
\hline Min. Temperature-6 & -0.006 & Wind Speed-6 & -0.281 \\
\hline Min. Temperature-7 & 0.121 & Wind Speed-7 & 0.059 \\
\hline
\end{tabular}

Table 5. Multiple lineal regression parameters of the developed prediction model for airborne protein concentrations.

\begin{tabular}{|c|c|c|c|c|c|c|}
\hline$R=0.6712$ & $R^{2}=0.4505$ & Adjusted $R^{2}=0.3973$ & $F(3,31)=8.4704$ & $p<0.0003$ & \multicolumn{2}{|c|}{ Std. Error of Estimate: 0.0319} \\
\hline $\mathrm{N}=35$ & Beta & Std. Err. Beta & B & Std. Err. B & $\mathrm{t}(31)$ & $p$-level \\
\hline Intercept & & & 0.4471 & 0.0458 & 9.7642 & 0.0000 \\
\hline $\mathrm{RH}$ & -0.3652 & 0.1352 & $-1.529 \times 10^{-3}$ & 0.0006 & -2.7006 & 0.0111 \\
\hline DewP -4 & -0.4531 & 0.1407 & $-7.130 \times 10^{-3}$ & 0.0022 & -3.2197 & 0.0030 \\
\hline Spores & 0.4231 & 0.1388 & $2.409 \times 10^{-4}$ & 0.0001 & 3.0484 & 0.0047 \\
\hline
\end{tabular}

RH: relative humidity; DewP -4: dew point of four days before; Spores: airborne B. cinerea conidia concentration. B: regression equation coefficients. Beta: standardized partial regression coefficients, which indicates the relative importance of each independent variable within the equation.

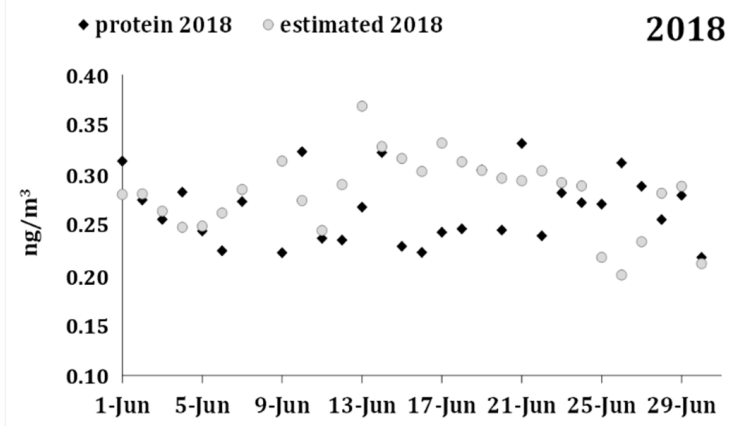

Figure 7. Graph of the detected airborne protein concentrations in 2018 and the forecast values obtained by the developed regression model (Table S5). 
Table 6. $T$-test for dependent samples between real and forecast values of airborne protein concentrations in 2018. Marked differences are significant at $p<0.05$.

\begin{tabular}{ccccccccc}
\hline Variable & Mean & Std. Dv. & N & Diff. & Std. Dv. Diff. & t & df & $p$ \\
\hline Protein 2018 & 0.266 & 0.034 & & & & & & \\
Forecast 2018 & 0.282 & 0.038 & 29 & -0.016 & 0.052 & -1.614 & 28 & 0.118 \\
\hline
\end{tabular}

\section{Discussion}

The identification of new biosensors to detect the risk of plant diseases is a subject of special importance at present time, since the changes on the global climate system have also a significant impact on the distribution of crop pest and diseases. An alteration of their frequency and severity with a high variability, depending on the crop-pest system and the geographical area, is projected. Impacts caused by climate change on agroecosystems were assessed, studying a wide range of regions and crops. These studies show that negative impacts on crop yields was more common than positive impacts [33]. Among the different crop species, the vine was widely studied in relation to climate change due to its high sensitivity to climatic conditions, with a special interest since their cultivation areas are enclosed in Mediterranean climate regions, which are important biodiversity sources at global scale [34-36]. The temperature increase is expected to promote higher development and reproductive rates of plant pathogens, therefore an increase in crop disease severity is estimated [37]. Additionally, variations in rainfall occurrence and their intensity, can favour fungal and bacterial species since infection, sporulation and dispersal processes of many of these species depends on humidity, increasing their occurrence as humidity periods increase [38,39]. Different crop-disease combinations could become problematic depending on the considered area, increasing the failure risk of current and future crop-protection strategies [37,40]. The prediction of crop-pest relationship evolution is an essential issue to achieve a stable crop production in the future based on sustainable strategies for crop and disease management [40].

Several warning systems for B. cinerea have been developed for some crop systems, based on conditions highly conducive to conidia germination and host penetration for disease development [41]. Current knowledge on conidia behaviour is mainly based on interpreting germinative growth during artificial inoculation, in which the plants are sprayed with conidia suspensions, supplemented in some cases with nutrients to increase the possibility of tissue penetration otherwise resistant to infection [42]. The present study provides valuable information about germination process of this pathogen in field conditions. Our study allows determining the influence of the main environmental factors and supplies the use of airborne protein concentrations as an indicator of the disease development stage and severity of fungal outbreak. The combination of immunological techniques and aerobiological monitoring improves the disease detection limit, increasing the sensitivity towards $B$. cinerea fungal material, what supposes an improvement of the effectiveness of epidemiological models based on meteorological and airborne conidia concentrations.

We observed the strong influence of meteorological conditions on fungal pathogen development, since we observed variations on $B$. cinerea airborne conidia related with weather conditions. The highest daily $B$. cinerea airborne conidia concentrations were recorded during periods with favourable temperature and humidity conditions for the fungus in both years. These optimum conditions were detected during a temperature-increase period that ranged the optimum $20-22{ }^{\circ} \mathrm{C}$ mean temperature, considered as optimal temperature for fungal sporulation, conidia germination and infection development [43-45]. Furthermore, the fungus wetness requirement of relative humidity higher than $95 \%$ [46] was also reached during this period, since the high conidia concentrations were recorded just after a continuous and abundant rain period. In the case of 2018, we also detected the highest B. cinerea conidia concentrations coinciding with favourable conditions for fungus development. During the two identified peak periods, we recorded mean temperature values around $20^{\circ} \mathrm{C}$, and a previous period of continuous rainfall that could increase the relative 
humidity levels, reaching the fungus wetness requirement. In addition to meteorological conditions favourable for plant infection and the presence of the pathogen, a susceptible phenological stage of the host is required for the occurrence of any plant disease. According to this, we considered the flowering ( $\mathrm{S} 6-\mathrm{BBCH}$ scale) as one of the most vulnerable grapevine phenological stages to $B$. cinerea infection. For the Ribeiro PDO vineyard area, González-Fernández et al. [16] previously found that the highest airborne conidia levels are usually recorded near to the flowering phenological stage, thus indicating a higher activity and fungal development in this period. The bioclimatic indicator developed for this pathogen based on the Magarey model, gave as a result that the flowering stage is one of the most susceptible stages to infection [16].

Considering the applied statistical analysis, the PCA applied on 2017 data correlated in the first component the airborne protein concentrations with mean and maximum temperatures. This relation shows the influence of temperature on the germination of $B$. cinerea conidia, which is a complex process with specific requirements to occur, within a range of temperature and relative humidity [44]. Our study detected that raises in protein levels coincided with the increase in airborne conidia concentrations as well as an increase of mean temperature in 2017. Chen and Hsieh [47] found a thermal range for germination of B. cinerea conidia of 16 to $28{ }^{\circ} \mathrm{C}$, what agree with Latorre and Rioja [48] who pointed out an optimum temperature of $20^{\circ} \mathrm{C}$ for conidia germination. Similar values were found in the studied vineyard, with and average mean temperature of $18.13^{\circ} \mathrm{C}$ and an average maximum temperature of $25.71^{\circ} \mathrm{C}$ during the entire considered flowering period in 2017. In the third component, the 2017 PCA grouped the B. cinerea conidia concentrations together with wind speed, which reflects the dispersion effect of wind on Botrytis species propagules, being the predominant dispersal mechanism of these dry conidia [42]. The 2018 PCA indicated a statistical relationship between airborne conidia and protein concentrations, grouped in the third component with an inverse relation. This correlation could reflect the inhibitory effect of high conidia concentrations on conidia germination reported for B. cinerea and other fungal species [49-51]. Scharrock et al. [52] reported the production of inhibitors for $B$. cinerea fungal growth and germination at concentrations up to $1 \times 10^{6}$ conidia $/ \mathrm{mL}$ threshold as part of the self-inhibition strategy. We observed this effect during the development of the standard curve in the first point of highest conidia concentration, with a value of $6.79 \times 10^{5}$ conidia $/ \mathrm{mL}$. The obtained equation of logarithmic adjust shows this inhibitory effect, since the highest conidia concentration values didn't generate a notable increase in absorbance from a certain value, tending to the curved part of the logarithmic function (Figure 3). Nassr and Barakat [31] also found similar results in their study of different factors affecting $B$. cinerea conidia germination, since they observed the formation of conidia clots and loss of germination ability at concentrations above $4 \times 10^{5}$ conidia $/ \mathrm{mL}$. Regarding the Spearman's correlation test, the correlations found for airborne conidia were mainly with temperature variables and wind speed of the 5-6-7 days before, and water-related variables (relative humidity and rainfall) of the 2-3-4 days before. These findings reinforce the obtained results by means of the PCA analysis, and agree with the stated by other authors who pointed out the seven-days period as required for fungal sporulation $[15,53]$. In the case of the protein concentrations, we found that most of significant correlations coincided on the 3 to 4 days before, mainly of mean, maximum and minimum temperatures, and dew point. We also found a strong correlation with relative humidity of the same day. This period of three to four days agrees with the indicated period by González-Fernández et al. [16], who found a period between four to six days (depending on the phenological stage under propitious meteorological conditions) for conidia germination and plant infection since the detection of conidia presence.

In many patho-systems, infection develops in the presence of a film of water on susceptible plant tissues. The role of water and nutrients in germination have been long recognized, however the pathogen is also able to infect plant tissues without a film of water on plant surfaces $[41,54,55]$. Several authors pointed out that $B$. cinerea infections occur under high relative humidity conditions with values higher than $90 \%[43,46,56,57]$. 
This humidity requirement can be met due to the occurrence of rain, drizzle or mist that can produce condensation on vine bunches or other plant surfaces. Moreover, water condensation because of evapotranspiration can be enough to initiate conidia germination and plant infection under field conditions [48]. In addition to the role of water, exogenous nutrients are a key factor required for conidia germination and the subsequent infection process [41]. During flowering, the pathogen uses pollen and sugary compounds produced by the plant for conidia germination, such as sugary stigmatic fluids secreted for the growth of the pollen tube [23,42]. The negative statistical influence of water-related variables on germinative protein concentrations detected in the regression model could be explained by the relevance of nutrient's presence for conidia germination, since condensed water can produce a dilution or wash of nutrients in sugary solutions from plant surfaces. Elad and Yunis [58] demonstrated that nutrients enhance B. cinerea conidia germination, since they found that washing off nutrients led to a decrease in disease incidence. They found that no infection occurred when cucumber fruits were inoculated with $B$. cinerea conidia and no nutrients were applied, as well as a reduction of $21 \%$ infection in petal-bearing fruits that were washed before inoculation with respect to those which were not washed.

\section{Conclusions}

The main objective of immunodetection of the pathogen Botrytis cinerea was achieved, with an approximation to quantification by means of the developed standard curve. Our results contribute to the obtaining of new tools towards the detection of possible diseases in widely used crops such as Vitis vinifera, since this study is one of the first attempts in which immunological techniques were extrapolated to wine-growing field conditions. Additionally, we detected a statistically-significant influence of different meteorological variables on atmospheric $B$. cinerea conidia concentrations and its possible relation with germination process. Airborne spore concentrations have been widely used for potential infection risk on aerobiological studies, and it could be complemented with the quantification of germinative material suspended into the aerosol as this indicates the exposition of plants to the real infective ability of the pathogen.

The obtained immune-enzymatic method supposes a fast sample processing that can reveal the germinative material atmospheric load on the vineyard atmosphere. After the initial outlay on reagents and antibodies for the implementation of these immunological techniques, the cost is largely amortized since a single ELISA plate can analyze a large number of daily samples, always using the same reagents. Furthermore, rapid detection of B. cinerea in samples could be evaluated by using LFD (Lateral Flow Device) tests which are available for the optimizing of economic cost, as used in other pathosystems. The sensitivity offered by the applied ELISA analysis allows identifying with great accuracy the protein load of the atmosphere at a given moment, knowing the levels of germination and driving conditions. These data are much more accurate than approximations based only on weather forecasts for disease management. Furthermore, the combination of these techniques with the aerobiological monitoring lead to a more reasoned treatment schedule due to the detection of the main fungal outbreaks, improving the effectiveness of the applied phytosanitary treatments and reducing the fungicide costs.

Supplementary Materials: The following are available online at https:/ / www.mdpi.com/article/10 .3390 /agronomy11071441/s1, Table S1: Data of airborne B. cinerea conidia concentrations (Spores, in spores $/ \mathrm{m}^{3}$ ), protein concentrations (Protein, in $\mathrm{ng} / \mathrm{m}^{3}$ ), mean temperature in ${ }^{\circ} \mathrm{C}$ (Tmean) and rainfall in $\mathrm{L} / \mathrm{m}^{2}$ (Rain) during the study period in 2017. Table S2: Date of start and end of the phenological stages 61, 65 and 69 (BBCH scale) of the considered grapevine varieties 'Treixadura', 'Godello', 'Loureira' and 'Albariño' in 2017. Table S3: Data of airborne B. cinerea conidia concentrations (Spores, in spores $/ \mathrm{m}^{3}$ ), protein concentrations (Protein, in $\mathrm{ng} / \mathrm{m}^{3}$ ), mean temperature in ${ }^{\circ} \mathrm{C}$ (Tmean) and rainfall in $\mathrm{L} / \mathrm{m}^{2}$ (Rain) during the study period in 2018. Table S4: Date of start and end of the phenological stages 61, 65 and 69 (BBCH scale) of the considered grapevine varieties 'Treixadura', 'Godello', 'Loureira' and 'Albariño' in 2018. Table S5: Data of B. cinerea airborne protein concentrations 
of 2018 (Protein), and forecast values for the same year obtained from the developed regression model (Estimated). Protein values are expressed in $\mathrm{ng} / \mathrm{m}^{3}$.

Author Contributions: Conceptualization, E.G.-F., R.K. and F.J.R.-R.; methodology, R.K. and E.G.-F.; software, E.G.-F. and M.F.-G.; formal analysis, E.G.-F., F.J.R.-R. and R.K.; investigation, E.G.-F., R.K., R.O., M.F.-G.; resources, R.K. and F.J.R.-R.; writing-original draft Preparation: E.G.-F.; writingreview and editing, R.K., F.J.R.-R. and E.G.-F.; supervision, R.K. and F.J.R.-R.; project administration: F.J.R.-R., R.K., and M.F.-G.; funding acquisition: F.J.R.-R. and R.K. All authors have read and agreed to the published version of the manuscript.

Funding: Innovate Project funding is acknowledged: Innovate UK Project 132749 "PROFITS—Semiautomated on-site quantification of airborne pathogen inoculum to predict the strawberry fruit rot risks". This work was partially funded by Xunta de Galicia CITACA Strategic Partnership (Reference: ED431E 2018/07), and the VITICAST 20190020007473 project of the Agriculture, Fisheries and Food Ministry of Spain Government. González-Fernández E. was supported by the FPU grant from Ministry of Sciences, Innovation and Universities of Spain Government (FPU15/03343).

Institutional Review Board Statement: Not applicable.

Informed Consent Statement: Not applicable.

Data Availability Statement: Not applicable.

Acknowledgments: The authors thank "Cooperativa Vitivinícola del Ribeiro S.C.G." for its collaboration.

Conflicts of Interest: The authors declare no conflict of interest. The funders had no role in the design of the study; in the collection, analyses, or interpretation of data; in the writing of the manuscript, or in the decision to publish the results.

\section{References}

1. Bois, B.; Zito, S.; Calonnec, A. Climate vs. grapevine pests and diseases worldwide: The first results of a global survey. OENO One 2017, 51, 133-139. [CrossRef]

2. Oliveira, M.; Guerner-Moreira, J.; Mesquita, M.M.; Abreu, I. Important phytopathogenic airborne fungal spores in a rural area: Incidence of Botrytis cinerea and Oidium spp. Ann. Agric. Environ. Med. 2009, 16, 197-204. [PubMed]

3. Rodríguez-Rajo, F.J.; Jato, V.; Fernández-González, M.; Aira, M.J. The use of aerobiological methods for forecasting Botrytis spore concentrations in a vineyard. Grana 2010, 49, 56-65. [CrossRef]

4. González-Domínguez, E.; Caffi, T.; Ciliberti, N.; Rossi, V. A Mechanistic Model of Botrytis cinerea on Grapevines That Includes Weather, Vine Growth Stage, and the Main Infection Pathways. PLoS ONE 2015, 10, e0140444. [CrossRef]

5. Stevens, R.B. Cultural practices in disease control. In Plant Pathology: An Advanced Treatise; Horsfall, J.G., Dimond, A.E., Eds.; Academic Press: Cambridge, MA, USA, 1960; Volume 3, pp. 357-429.

6. Agrios, G.N. Plant Pathology, 5th ed.; Elsevier-Academic Press: New York, NY, USA, 2005; p. 952.

7. Keller, M.; Viret, O.; Cole, M. Botrytis cinerea Infection in Grape Flowers: Defense Reaction, Latency and Disease Expression. Phytopathology 2003, 93, 316-322. [CrossRef] [PubMed]

8. Kretschmer, M.; Kassemeyer, H.; Hahn, M. Age-dependent Grey Mould Susceptibility and Tissue-specific Defence Gene Activation of Grapevine Berry Skins after Infection by Botrytis cinerea. J. Phytopathol. 2007, 155, 258-263. [CrossRef]

9. Pezet, R.; Pont, V. Infection florale et latence de Botrytis cinerea dans les grappes de Vitis vinifera (var. Gamay). Rev. Suisse Vitic. Arboric. Hortic. 1986, 18, 317-322.

10. Holz, G.; Coertze, S.; Basson, E.J. Latent infection of Botrytis cinerea in grape pedicels leads to postharvest decay. Phytopathology 1997,87, S43.

11. Wolf, T.K.; Baudin, A.B.A.M.; Martínez-Ochoa, N. Effect of floral debris removal from fruit clusters on botrytis bunch rot of Chardonnay grapes. Vitis J. Grapevine Res. 1997, 36, 27-33. [CrossRef]

12. Fernández-González, M.; Rodríguez-Rajo, F.J.; Jato, V.; Aira, M.J.; Ribeiro, H.; Oliveira, M.; Abreu, I. Forecasting ARIMA models for atmospheric vineyard pathogens in Galicia and Northern Portugal: Botrytis cinerea spores. Ann. Agric. Environ. Med. 2012, 19, 255-262.

13. González-Fernández, E.; Piña-Rey, A.; Fernández-González, M.; Rodríguez-Rajo, F.J. Effect of environmental conditions and phenology in the dispersal of secondary Erysiphe necator conidia in a vineyard. Vitis J. Grapevine Res. 2019, 58, 49-58. [CrossRef]

14. Martínez-Bracero, M.; Alcázar, P.; Velasco-Jiménez, M.J.; Galán, C. Fungal spores affecting vineyards in Montilla-Moriles Southern Spain. Eur. J. Plant Pathol. 2019, 153, 1-13. [CrossRef]

15. Carisse, O.; Savary, S.; Willocquet, L. Spatiotemporal relationships between disease development and airborne inoculum in unmanaged and managed Botrytis leaf blight epidemics. Phytopathology 2008, 98, 38-44. [CrossRef] 
16. González-Fernández, E.; Piña-Rey, A.; Fernández-González, M.; Aira, M.J.; Rodríguez-Rajo, F.J. Identification and evaluation of the main risk periods of Botrytis cinerea infection on grapevine based on phenology, weather conditions and airborne conidia. $J$. Agric. Sci. 2020, 158, 88-98. [CrossRef]

17. Meyer, U.M.; Spotts, R.A.; Dewey, F.M. Detection and Quantification of Botrytis cinerea by ELISA in Pear Stems During Cold Storage. Plant Dis. 2000, 84, 1099-1103. [CrossRef]

18. Dewey, F.M.; Yohalem, D. Detection, quantification and immunolocalisation of Botrytis species. In Botrytis: Biology, Pathology and Control; Elad, Y., Williamson, B., Tudzynski, P., Delen, N., Eds.; Springer: Dordrecht, The Netherlands, 2007 ; pp. 181-194.

19. Blanco-Ward, D.; García, J.M.; Jones, G.V. Spatial climate variability and viticulture in the Miño River Valley of Spain. Vitis J. Grapevine Res. 2007, 46, 63-70.

20. Orriols, I.; Vázquez, I.; Losada, A. Variedades gallegas. Terruños 2006, 16, 11-18.

21. Casares, J.M. Ficha Técnica. Denomicación de Orixe Ribeiro. Available online: www.mediorural.xunta.gal (accessed on 15 January 2021).

22. Meier, U. Growth Stages of Mono and Dicotyledonous Plants—BBCH Monograph, 2nd ed.; Julius Kühn-Institut (JKI); Federal Biological Research Centre for Agriculture and Forestry: Quedlingburg, Germany, 2001; p. 158. [CrossRef]

23. Vasconcelos, M.C.; Greven, M.; Winefield, C.S.; Trought, M.C.T.; Raw, V. The Flowering Process of Vitis vinifera: A Review. Am. J. Enol. Vitic. 2009, 60, 411-434.

24. Ministerio para la Transición Ecológica. Gobierno de España. Shapefile of Biogeographic Regions in Spain. Available online: https://www.miteco.gob.es/es/cartografia-y-sig/ide/descargas/biodiversidad/regiones-biogeograficas.aspx (accessed on 18 July 2021).

25. MeteoGalicia. Galician Institute for Meteorology and Oceanography, Santiago de Compostela, Spain. Environment, Territory and Infrastructure Department of Galician Regional Government. Available online: http:/ /www.meteogalicia.gal/web/index.action (accessed on 17 July 2021).

26. Hirst, J.M. An Automatic Volumetric Spore Trap. Ann. Appl. Biol. 1952, 39, 257-265. [CrossRef]

27. Galán, C.; Cariñanos, P.; Alcázar, P.; Domínguez, E. Spanish Aerobiology Network (REA): Management and Quality Manual; University of Córdoba Publication Service: Córdoba, Spain, 2007; p. 61.

28. Miclea, R.V.; Suciu, L.A.; Puia, C.E. In Vitro Studies Regarding the Morphology of Botrytis cinerea Pers. Isolated from Geranium Plants. ProEnvironment 2012, 5, 60-66.

29. Wang, Y.; Yang, L.; Bai, Q.R. First Report of Botrytis cinerea Causing Gray Mold of Peperomia ferreyrae in Jilin Province, China. Plant Dis. 2017, 101, 250. [CrossRef]

30. Galán, C.; Ariatti, A.; Bonini, M.; Clot, B.; Crouzy, B.; Dahl, A.; Fernández-González, D.; Frenguelli, G.; Gehrig, R.; Isard, S.; et al. Recommended terminology for aerobiological studies. Aerobiologia 2017, 33, 293-295. [CrossRef]

31. Nassr, S.; Barakat, R. Effect of Factors on Conidium Germination of Botrytis cinerea in vitro. Int. J. Plant Soil Sci. 2013, 2, 41-54. [CrossRef]

32. Tipping, M.E.; Bishop, C.M. Probabilistic Principal Component Analysis. J. R. Stat. Soc. Series B Stat. Methodol. 1999, 61, 611-622. Available online: jstor.org/stable/2680726 (accessed on 15 January 2021). [CrossRef]

33. IPCC. Intergovernmental Panel on Climate Change. Climate Change 2014: Synthesis Report. Contribution of Working Groups I, II and III to the Fifth Assessment Report of the Intergovernmental Panel on Climate Change; Core Writing Team, Pachauri, R.K., Meyer, L.A., Eds.; IPCC: Geneva, Switzerland, 2014; 151p.

34. Jones, G.V.; White, M.A.; Cooper, O.R.; Storchmann, K. Climate Change and Global Wine Quality. Clim. Chang. 2005, 73, 319-343. [CrossRef]

35. Meier, N.; Rutishauser, T.; Pfister, C.; Wanner, H.; Luterbacher, J. Grape Harvest Dates as a proxy for Swiss April to August Temperature Reconstructions back to AD 1480. Geophys. Res. Lett. 2007, 34, L20705. [CrossRef]

36. Hannah, L.; Roehrdanz, P.R.; Ikegami, M.; Shepard, A.V.; Shaw, M.R.; Tabor, G.; Zhi, L.; Marquet, P.A.; Hijmans, R.J. Climate change, wine, and conservation. Proc. Natl. Acad. Sci. USA 2013, 110, 6907-6912. [CrossRef]

37. Lamichhane, J.R.; Barzman, M.; Booij, K.; Boonekamp, P.; Desneux, N.; Huber, L.; Kudsk, P.; Langrell, S.R.H.; Ratnadass, A.; Ricci, P.; et al. Robust cropping systems to tackle pests under climate change. A review. Agron. Sustain. Dev. 2015, 35, 443-459. [CrossRef]

38. Huber, L.; Gillespie, T.J. Modeling Leaf Wetness in Relation to Plant Disease Epidemiology. Ann. Rev. Phytopathol. 1992, 30, 553-577. [CrossRef]

39. Juroszek, P.; von Tiedemann, A. Potential strategies and future requirements for plant disease management under a changing climate. Plant Pathol. 2011, 60, 100-112. [CrossRef]

40. Shaw, M.W.; Osborne, T.M. Geographic distribution of plant pathogens in response to climate change. Plant Pathol. 2011, 60, 31-43. [CrossRef]

41. Elad, Y.; Williamson, B.; Tudzynski, P.; Delen, N. Botrytis spp. and diseases they cause in agricultural systems-An introduction. In Botrytis: Biology, Pathology and Control; Elad, Y., Williamson, B., Tudzynski, P., Delen, N., Eds.; Springer: Dordrecht, The Netherlands, 2007; pp. 1-8.

42. Holz, G.; Coertze, S.; Williamson, B. The ecology of Botrytis on plant surfaces. In Botrytis: Biology, Pathology and Control; Elad, Y., Williamson, B., Tudzynski, P., Delen, N., Eds.; Springer: Dordrecht, The Netherlands, 2007; pp. 9-27. 
43. Broome, J.C.; English, J.T.; Marois, J.J.; Latorre, B.A.; Avilés, J.C. Development of an infection model for Botrytis bunch rot of grape based on wetness duration and temperature. Phytopathology 1995, 85, 97-102. [CrossRef]

44. Thomas, C.S.; Marois, J.J.; English, J.T. The effects of wind speed, temperature and relative humidity on development of aerial mycelium and conidia of Botrytis cinerea on grape. Phytopathology 1988, 78, 260-265. [CrossRef]

45. Ciliberti, N.; Fermaud, M.; Roudet, J.; Rossi, V. Environmental conditions affect Botrytis cinerea infection of mature grape berries more than the strain or transposon genotype. Phytopathology 2015, 105, 1090-1096. [CrossRef] [PubMed]

46. Magarey, R.D.; Sutton, T.B.; Thayer, C.L. A Simple Generic Infection Model for Foliar Fungal Plant Pathogens. Phytopathology 2005, 95, 92-100. [CrossRef] [PubMed]

47. Chen, C.H.; Hsieh, T.F. First report of Botrytis cinerea causing gray mold of Jamaica cherry in Taiwan. Plant Pathol. Bull. 2009, 18, 119-123.

48. Latorre, B.A.; Rioja, M.E. The effect of temperature and relative humidity on conidial germination of Botrytis cinerea. Cienc. Investig. Agrar. 2002, 29, 67-72. [CrossRef]

49. Allen, P.J. The role of a self-inhibitor in the germination of rust uredospores. Phytopathology 1995, 215, $259-266$.

50. Bacon, C.W.; Sussman, A.S.; Paul, A.G. Identification of a self-inhibitor from spores of Dictyostelium discoideum. J. Bacteriol. 1973, 113, 1060-1063. [CrossRef]

51. Barrios-Gonzales, J.; Martinez, C.; Aguilera, A.; Raimbault, M. Germination of concentrated suspensions of spores from Aspergillus niger. Biotechnol. Lett. 1989, 11, 551-554. [CrossRef]

52. Scharrock, K.; Henzell, R.; Parry, F. Self-Inhibition of Germination of Botrytis Cinerea Conidia; Horticulture and Food Research Institute of New Zealand: Hamilton, New Zealand, 2001.

53. Jeger, M.J. Relating disease progress to cumulative numbers of trapped spores: Apple powdery mildew and scab epidemics in sprayed and unsprayed orchard plots. Plant Pathol. 1984, 33, 517-523. [CrossRef]

54. Williamson, B.; Duncan, G.H.; Harrison, J.G.; Harding, L.H.; Elad, Y.; Zimand, G. Effect of humidity on infection of rose petals by dry-inoculated conidia of Botrytis cinerea. Mycol. Res. 1995, 99, 1303-1310. [CrossRef]

55. Elad, Y. Changes in disease epidemics on greenhouse grown crops. Acta Hortic. 2000, 534, 213-220. [CrossRef]

56. Yunis, H.; Shtienberg, D.; Elad, Y.; Mahrer, Y. Qualitative approach for modelling outbreaks of grey mould epidemics in non-heated cucumber greenhouses. Crop. Prot. 1994, 13, 99-104. [CrossRef]

57. Eden, M.A.; Hill, R.A.; Beresford, R.; Stewart, A. The influence of inoculum concentration, relative humidity, and temperature on infection of greenhouse tomatoes by Botrytis cinerea. Plant Pathol. 1996, 45, 795-806. [CrossRef]

58. Elad, Y.; Yunis, H. Effect of Microclimate and Nutrients on Development of Cucumber Gray Mold (Botrytis cinerea). Phytoparasitica 1993, 21, 257-268. [CrossRef] 